\author{
N.I. Kopylov ${ }^{1}$, E.P. Solotchina ${ }^{2}$ \\ ${ }^{1}$ Institute of Solid State Chemistry and Mechanochemistry \\ of the Siberian Branch of the Russian Academy of Sciences, Novosibirsk, Russia; \\ ${ }^{2}$ V.S. Sobolev Institute of Geology and Mineralogy \\ of the Siberian Branch of the Russian Academy of Sciences, Novosibirsk, Russia \\ (E-mail:kolyubov@narod.ru)
}

\title{
Study of the thermal properties of clays from the Krasnoyarsk and Sukpak deposits of Tuva
}

\begin{abstract}
The most important factor in the development of industry and the construction industry of individual and hard-to-reach regions is the availability of their respective raw materials and energy base. Their possible effective use can often be difficult due to difficult geological conditions, lack of required transport connections and removal from industrial centers. So, in particular, more than a dozen industrial deposits of fossil raw materials and clay rocks located in hard-to-reach areas are known on the territory of the Republic of Tuva and their extraction is currently not cost-effective. Therefore, available low-grade raw materials with the introduction of various additional components can be used as the main raw material. The latter requires a certain amount of complex research, namely, the study of the dynamics of the behavior of the initial components, their mixtures, the batching compositions during roasting, the development of technology parameters using new raw materials, etc. In this connection, in the first stage of the research in this paper using a number of methods of physicochemical analysis the dynamics of the phase transformations occurring in the material of the rare-earth clays of the Sukpak and Krasnoyarsk deposits of Tuva is studied, with their heating in the temperature range up to $\sim 1020-1025^{\circ} \mathrm{C}$. As a result, the stages of successive thermal decomposition of the material were determined, namely, the removal of sorption and hydrated moisture, the destruction of hydroaluminosilicates, the decomposition of magnesian calcite, and the initial formation of high-temperature aluminosilicate structures.
\end{abstract}

Keywords: thermal, X-ray phase analysis, X-ray fluorescent analysis, clays, oxides, carbonates, silicates, aluminosilicates.

\section{Introduction}

One of the most important factors for the development of the construction industry of remote and hardto-reach regions is the availability of an appropriate raw materials base and its efficient use. However, often existing internal sources of raw materials are not used enough in regions. So, in particular, more than a dozen industrial deposits of clay rocks are known on the territory of Tuva [1-4]. The presence of $45-62 \% \mathrm{of} \mathrm{SiO}_{2}$ and $13-18 \%$ of $\mathrm{Al}_{2} \mathrm{O}_{3}$ in them allows them to be attributed to semi-acid clays (herein and after, $\% \mathrm{wt}$.). They contain significant concentrations of alkaline earth metal compounds (5-10\%), iron oxides (6-9\%). Similar clay rocks are divided into two groups:

- smectite, with predominance of the mineral nontronite $(\mathrm{Fe}, \mathrm{Al})_{2}\left[\mathrm{Si}_{4} \mathrm{O}_{10}\right] \cdot(\mathrm{OH})_{2} \cdot \mathrm{nH}_{2} \mathrm{O}$ in the clays of this group;

- micaceous, rock-forming mineral in which is illite (a kind of hydromuscovite) $-\mathrm{K}_{<1} \mathrm{Al}_{2}[(\mathrm{Si}$, $\left.\mathrm{Al})_{4} \mathrm{O}_{10}\right] \cdot \mathrm{OH}_{2} \cdot \mathrm{nH}_{2} \mathrm{O}$.

The latter in terms of plasticity refer to a moderately and slightly plastic group. They are also lightbinder material. Their refractory temperatures are in the range of $1180-1250^{\circ} \mathrm{C}$ and have a small sintering interval $\left(\sim 30-50^{\circ} \mathrm{C}\right)$.

At a firing temperature of smectite clay up to $1100^{\circ} \mathrm{C}$, the crock of the cake has water absorption (B) equal to $8-10 \%$, which indicates its porous structure. Therefore, in order to obtain a dense crock $(\mathrm{B}<5 \%)$, as a rule, clays of the hydromica group are used.

An analysis of the geography of occurrence of clay rocks of Tuva showed that the existing clays of the micaceous group on the territory of the Republic were in hard-to-reach areas of the region and their extraction was currently not possible. Therefore, mainly montmorillonite clays of the Krasnoyarsk and Sukpak deposits are used as the main plastic raw material in practice. These clays are low-dispersed, moderately and low-plastic, with high and medium sensitivity to drying, characterized by a small interval of sintering.

For effective work of production on this raw material it is necessary to work out for it the required technological mode of roasting. And to obtain the specified technological properties of the material of these 
clays, it is necessary to additionally produce specially selected effective additives for them. Natural fluxescan be these additives. Deposits of qualitative natural fluxes - pegmatites (a mixture of quartz and feldspars) are found in the Republic, but are in inaccessible mountainous terrain and are not yet developed due to the difficulty of their development. Therefore, low-quality raw materials with the addition of various man-made materials such as quarry wastes, asbestos and other technological products are used as additives in practice.

By the time, only solid brick of M75 grade is produced from ceramic materials in the amount of 2-3 thousand pieces per year by the construction industry of Tuva, with the annual requirement of about 20-22 thousand pieces of conditional brick. Missing requirements are covered by income from other regions. At the same time the cost of material increases by 1.5-1.7 times due to transportation costs [2].

With the purpose of more efficient use of raw materials for the construction industry, a number of works on improving the production of ceramic materials have been carried out recently $[2,3,5]$. Also, attempts were made to use the Khovu-Aksy dump slurry (plant «Tuvakobalt» wastes) in the production process of ceramic materials instead of natural fluxes $[6,7]$.

These preliminary experiments have shown the possibility of obtaining a ceramic material of a dense crock based on local clays and dump sludge of Khovu-Aksy. However, these experiments were of a trial nature. At the same time, the ecological factor was not taken into account, although the sludge of the KhovuAksy dumps contains 3.0 to $6.3 \%$ of arsenic [8]. How will the arsenic compounds present in the sludge behave in the process of production and further exploitation of ceramic products? This question remains open. Therefore, at the subsequent stage of research on the use of Khovu-Aksy dump wastes in the production of ceramic building materials, the environmental factor should be decisive, along with the study of the physical and technological properties of the materials of the initial charge and the products obtained.

In order to study the possibility of using the wastes of the Khovu-Aksy dump for the production of ceramic products and building materials as a flux at the initial stage of the research program, there was made a study of the phase transformations occurring during roasting, the initial components of the production of ceramic materials (clays of Sukpak and Krasnoyarsk deposits of Tuva, dump products of Khovu-Aksy), as well as their mixtures.

This report presents the results of studying the phase transformations occurring in the material of the clays under investigation during their calcination.

\section{Experimental}

Initial samples of clays were subjected to quantitative analysis for oxides by X-ray fluorescent method and X-ray phase analysis (XRD) to determine their mineral composition. The obtained results on the content of oxides in the samples of the investigated clays are presented in the Table.

$\mathrm{T}$ a b l e

\section{X-ray fluorescence analysis of starting materials}

\begin{tabular}{|c|l|l|l|l|l|l|l|l|l|l|l|l|l|l|l|l|c|}
\hline No. & $\begin{array}{l}\text { Starting ma- } \\
\text { terial }\end{array}$ & $\mathrm{SiO}_{2}$ & $\mathrm{Al}_{2} \mathrm{O}_{3}$ & $\mathrm{Fe}_{2} \mathrm{O}_{3}$ & $\mathrm{MgO}$ & $\mathrm{CaO}$ & $\mathrm{TiO}_{2}$ & $\mathrm{Na}_{2} \mathrm{O}$ & $\mathrm{K}_{2} \mathrm{O}$ & $\mathrm{SO}_{3}$ & $\mathrm{NiO}$ & $\mathrm{CuO}$ & $\mathrm{Co}_{3} \mathrm{O}_{4}$ & $\mathrm{P}_{2} \mathrm{O}_{5}$ & $\mathrm{MnO}^{\mathrm{M} O} \begin{array}{c}\mathrm{Amor} \\
\text { phous } \\
\text { phase }\end{array}$ \\
\hline 1 & $\begin{array}{l}\text { Krasnoyarsk } \\
\text { Clay }\end{array}$ & 55.73 & 14.26 & 6.20 & 2.48 & 6.36 & 0.75 & 2.17 & 2.24 & 0.51 & 0.006 & $\begin{array}{c}\text { Unde- } \\
\text { fined }\end{array}$ & $\begin{array}{c}\text { Unde- } \\
\text { fined }\end{array}$ & 0.22 & 0.10 & 8.22 \\
\hline 2 & $\begin{array}{l}\text { Sukpak } \\
\text { Clay }\end{array}$ & 49.76 & 14.83 & 7.26 & 3.22 & 8.24 & 0.83 & 1.15 & 2.17 & 0.26 & 0.008 & $\begin{array}{l}\text { Unde- } \\
\text { fined }\end{array}$ & $\begin{array}{c}\text { Unde- } \\
\text { fined }\end{array}$ & 0.32 & 0.16 & 11.05 \\
\hline
\end{tabular}

X-ray fluorescence silicate analysis of the samples was performed on an ARL-9900-XP ARL (Applied Research Laboratories) X-ray spectrometer. The sample was dried at $105^{\circ} \mathrm{C}$ for 1.5 hours, then it was calcined at $960{ }^{\circ} \mathrm{C}$ for 2.5 hours and mixed with a flux $(66.67 \%$ of lithium tetraborate, $32.83 \%$ of lithium metaborate, and 0.5 of lithium bromide) in a ratio of $1: 9$ (the total weight of the mixture is $5 \mathrm{~g}$ ). The mixture was melted in platinum crucibles in an induction furnace (Lifumat-2,0-Ox, Germany). State standard samples of the rock composition were used to verify the correctness of the analysis.

X-ray phase analysis was performed on an ARLXTRA powder diffractometer of Thermo Scientific ARL Products (Switzerland). The samples were ground in alcohol in an agate mortar and applied to a glass substrate of $2 \times 2 \mathrm{~cm}$ in size. The thickness of the preparation was $\sim 20 \mathrm{mg} / \mathrm{cm}^{2}$. The samples were scanned $\left(\mathrm{CuK}_{a}\right.$ radiation) in the range from $2^{\circ}$ to $65^{\circ}(2 \Theta)$ in steps of $0.05^{\circ}$, the scanning time at the point was $3 \mathrm{sec}$. 
The interpretation of X-ray diffraction patterns of minerals was compared with the reference cards of the International powder database «Power diffraction files» (PDF).

Thermal studies (DTA) were carried out using the Pauliick model derivatograph, Pauliick Erdei (Hungary), MOM-1000 type. The conditions are standard: the heating rate is $\sim 10 \mathrm{deg} / \mathrm{min}$, the air environment; the temperature limit is $900-1025^{\circ} \mathrm{C}$. The samples of the cinders of the investigated clays after thermal analysis were also studied for the phase composition by X-ray diffraction analysis. The data on the chemical, physical, chemical and thermochemical properties of individual natural compounds, minerals and clays available in the reference and scientific literature were used to process the results of the thermal analysis of the products under study [9-15].

\section{Thermal analysis of the Sukpak clay}

According to X-ray fluorescence analysis:

- The basis of the average sample of the Sukpak clay is quartz $\left(\alpha-\mathrm{SiO}_{2}\right)$ and magnesium containing calcite - $(\mathrm{Mg}, \mathrm{Ca}) \mathrm{CO}_{3}$;

- it contains a considerable amount of plagioclase, the sum of albite $\left(\mathrm{NaAlSi}_{3} \mathrm{O}_{8}\right)$ and anorthite $\left(\mathrm{CaAl}_{2} \mathrm{Si}_{2} \mathrm{O}_{8}\right)=(100-n) \mathrm{NaAlSi}_{3} \mathrm{O}_{8}+n \mathrm{CaAl}_{2} \mathrm{Si}_{2} \mathrm{O}_{8}$, where «n» can vary from 0 to 100 ;

- kaolinite - $\mathrm{Al}_{4}\left[\mathrm{Si}_{4} \mathrm{O}_{10}\right](\mathrm{OH})_{8}$ is also present; potassium feldspar, which represents aluminosilicates mainly of potassium (orthoclase, microcline - $\mathrm{K}\left[\mathrm{AlSi}_{3} \mathrm{O}_{10}\right]$, etc.); mica (aluminosilicates $\mathrm{AB}_{2-3}\left[\mathrm{~T}_{4} \mathrm{O}_{10}\right](\mathrm{OH}, \mathrm{F})$, where $\mathrm{A}-\mathrm{K}, \mathrm{Na}, \mathrm{Ca}$ and others, $\mathrm{B}-\mathrm{Al}, \mathrm{Mg}, \mathrm{Fe}$; $\left.\mathrm{T}-\mathrm{Si}, \mathrm{Al}\right)$; smectite, illite-smectite (solid solution of mica-like minerals, the compositions of which, according to the bibliography, belong to the high-silica mica: montmorillonites and saponites);

- the presence of hematite $\alpha-\mathrm{Fe}_{2} \mathrm{O}_{3}$ is noted.

According to the data of X-ray fluorescence analysis (see Table), the sample with relatively equal content of alumina $(14.83 \%)$ with Krasnoyarsk clay has lower contents of silicon oxide $(49.76 \%)$, sodium $(1.15 \%)$, but in somewhat larger amounts oxides of a number of other metals (iron, magnesium, calcium, potassium).

After carrying out the thermal analysis within the temperature up to $900{ }^{\circ} \mathrm{C}$, the mineral composition of the resulting cinder according to the X-ray phase analysis has undergone the following changes. There is a complete absence of magnesian calcite and kaolinitein the sample with the dominance of the quartz phase. Along with quartz, the dominant mineral is plagioclase. The product of thermolysis shows the presence of potassium feldspar, hematite, traces of mica, illite-smectite, and also the possible presence of karosite$\mathrm{KFe}_{3}\left[\mathrm{SO}_{4}\right]_{2}(\mathrm{OH})_{6}$.

The DTA curve of the thermogram (Fig. 1) shows a number of endothermic effects with temperature peaks at $100,540,680$, and $\sim 795^{\circ} \mathrm{C}$. The stages of mass loss (see curves of TG and DTG) are fixed by the final temperatures of $250,540,750$ and $800^{\circ} \mathrm{C}$. Sorbed and crystallization moisture is removed from the clay materialin the interval up to $\sim 250^{\circ} \mathrm{C}$. In the temperature range $\sim 435-620^{\circ} \mathrm{C}$, decomposition of kaolinite takes place: decomposition of weakly formed structures occursup to $\sim 500{ }^{\circ} \mathrm{C}$, and further $\left(\right.$ at $\left.\sim 500-600{ }^{\circ} \mathrm{C}\right)$, the ordered forms are destroyed with removal of structural (molecular) water and the release of amorphous phases of $\mathrm{Al}_{2} \mathrm{O}_{3}$ and $\mathrm{SiO}_{2}$.

Apparently, the process of decomposition of magnesian calcite beginsalready at temperatures of $\sim 620$ $650^{\circ} \mathrm{C}$. Initially, the decomposition process occurs with the release of $\mathrm{MgO}$ as an amorphous phase. Further, the decomposition of magnesian calcite is completed by the release of $\mathrm{CaO}$ and complete distillation of $\mathrm{CO}_{2}$ within the limits of temperatures $\sim 750-795^{\circ} \mathrm{C}$.

The DTGA of a sample of Sukpak clay subjected to additional abrasion in a mortar and heated in the temperature range up to $1025^{\circ} \mathrm{C}$ (see Fig. 2), practically confirmed the course of the thermal decomposition described by the curves of the thermogram curves of the first experiment (Fig. 1). However, there is an increase in mass loss in the temperature range of $80-250^{\circ} \mathrm{C}$ and a decrease in mass loss in the hightemperature stages of heating. As a result, the total mass loss was also significantly reduced. This is due to the fact that with additional processing (abrasion), there was a partial destruction of hydrated hydrosilicate structures and at the same time an increase in the sorption capacity of the material [15]. Analysis of the TG curve shows that the decomposition process of magnesian calcite is more clearly divided into two stages. At the temperature stage from temperatures of $\sim 580-600^{\circ} \mathrm{C}$ the effect of decomposition of magnesian calcite with the release of the amorphous phase of $\mathrm{MgO}$ is manifested. A fairly clear endoeffect at $740-770-820^{\circ} \mathrm{C}$ is due to further decomposition of calcite with the formation of an amorphous phase of $\mathrm{CaO}$ and $\mathrm{CO}_{2}$ distilling off. And further, at $\sim 900{ }^{\circ} \mathrm{C}$ the decomposition of the residual calcite is completed. Subsequent 
small effects at $900,930^{\circ} \mathrm{C}$, apparently, can be attributed to the residual decomposition of the most stable aluminosilicate phases and the formation of structures such as spinel or mullite based on amorphous active oxides formed during the decomposition of aluminosilicates and carbonates.

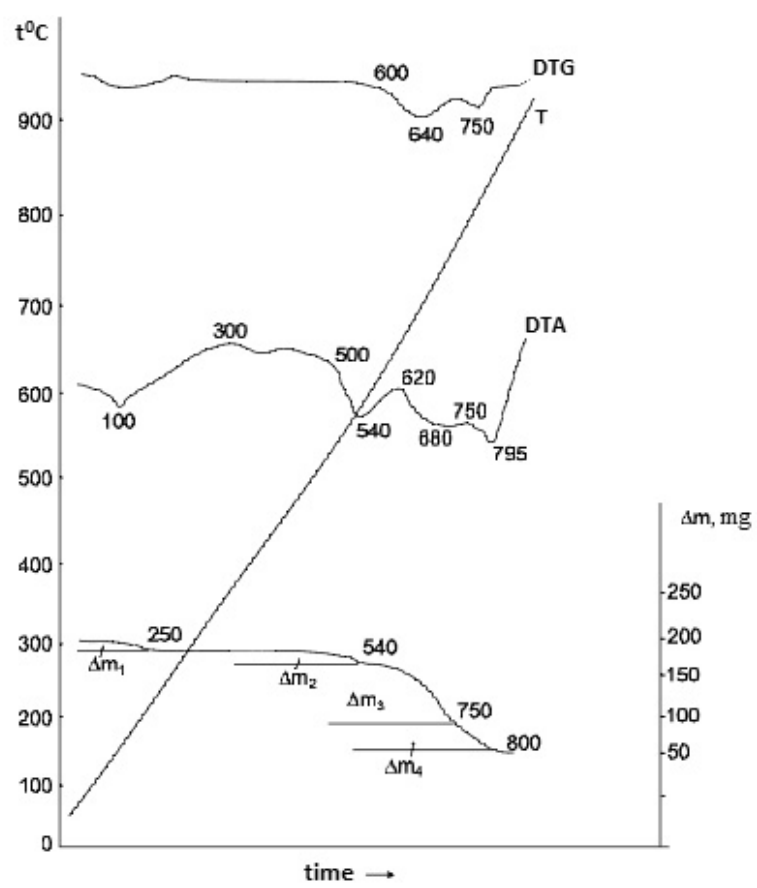

Figure 1. The thermogram of the Sukpak clay sample without additional treatment

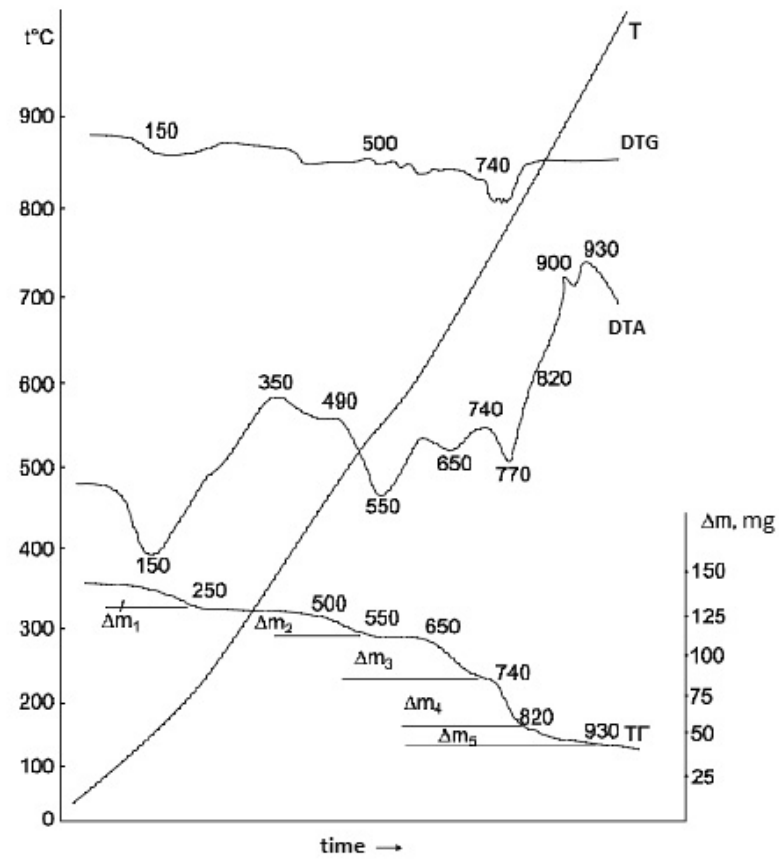

Figure 2. The thermogram of the Sukpak clay sample subjected to additional abrasion

The drop in the mass of the material when heated according to the TG curve is in accordance with the dynamics of the thermal decomposition of the sample presented above. It is carried out sequentially in several stages in the temperature intervals: $\sim 80-250{ }^{\circ} \mathrm{C}, \sim 440-600{ }^{\circ} \mathrm{C}, \sim 650-750{ }^{\circ} \mathrm{C}, \sim 770-900{ }^{\circ} \mathrm{C}$ with a loss of mass, respectively: $0.8-1.7 \% ; 2.2 \% ; 2.8-6.7 \% ; 4.9-5.6 \%$. The main weight loss $(\sim 80 \%)$ occurs at the last stage. The total mass loss is in the range of $\sim 11.7-15.2 \%$, depending on the conditions for the preliminary preparation of the sample and the temperature limit of heating at DTGA.

\section{Thermal analysis of the Krasnoyarsk clay}

According to the X-ray fluorescence analysis in the original sample of the Krasnoyarsk clay:

- quartz $\left(\alpha-\mathrm{SiO}_{2}\right)$; potassium feldspar (in particular, microcline and orthoclase- $\mathrm{K}$ [ $\left.\mathrm{AlSi}_{3} \mathrm{O}_{10}\right]$ ), plagioclase (albite $-\mathrm{Na}\left[\mathrm{AlSi}_{3} \mathrm{O}_{8}\right]$ and anorthite $\left.-\mathrm{Ca}\left[\mathrm{Al}_{2} \mathrm{Si}_{2} \mathrm{O}_{8}\right]\right)$, magnesian calcite $-(\mathrm{Mg}, \mathrm{Ca}) \mathrm{CO}_{3}$ dominate;

- there are such minerals as chlorite - $\left(\mathrm{Mg}, \quad \mathrm{Fe}^{2+}, \mathrm{Fe}^{3+}\right)_{6} \cdot\left[\mathrm{AlSi}_{3} \mathrm{O}_{10}\right](\mathrm{OH})_{8} ;$ kaolinite $\mathrm{Al}_{4}\left[\mathrm{Si}_{4} \mathrm{O}_{10}\right](\mathrm{OH})_{8}$; dioctahedral mica (muscovite type $-\mathrm{KAl}_{2}\left[(\mathrm{Si}, \mathrm{Al})_{4} \mathrm{O}_{10}\right](\mathrm{OH}, \mathrm{F})$ ); smectite and traces of illite-smectite;

- traces of hematite $-\mathrm{Fe}_{2} \mathrm{O}_{3}$, siderite $-\mathrm{FeCO}_{3}$ and goethite $-\mathrm{FeO}(\mathrm{OH})$ are noted.

In contrast to the Sukpak clay, potassium feldspar and plagioclase dominate in the composition of the Krasnoyarsk clay along with quartz and calcite. These minerals in the Sukpak clay are contained in a small amount. In addition, there are still chlorite and goethite, as well as sideritein the Krasnoyarsk clay. They were not found in the Sukpak clay.

Comparing the content of element oxides in the Krasnoyarsk and Sukpak clays (see Table), it should be noted that there is a greater content of quartz, sodium oxides and a fewer oxides of iron, magnesium and calciumin the Krasnoyarsk clay.

The character of the DTGA curve of the sample of the Krasnoyarsk clay subjected to preliminary abrasion (Fig. 3) is rather close to the character of the DTGA curves of the Sukpak clay, although it has some differences. Thus, with similar low-temperature endoeffects with temperature peaks at 160 and $540^{\circ}$, the subsequent course of the DTA and TG curves changes somewhat. High-temperature endoeffects of DTA (in the 
temperature range of $600-850^{\circ} \mathrm{C}$ ) are insignificant and weakly manifested. Only endoeffect with a peak at $750{ }^{\circ} \mathrm{C}$ is relatively clearly manifested. The TG curve smoothly extends from 440 to $600{ }^{\circ} \mathrm{C}$ and further from 700 to $800{ }^{\circ} \mathrm{C}$ with the continuation of some decrease in mass up to $900{ }^{\circ} \mathrm{C}$, in contrast to the TG curves of the sample of the Sukpak clay.

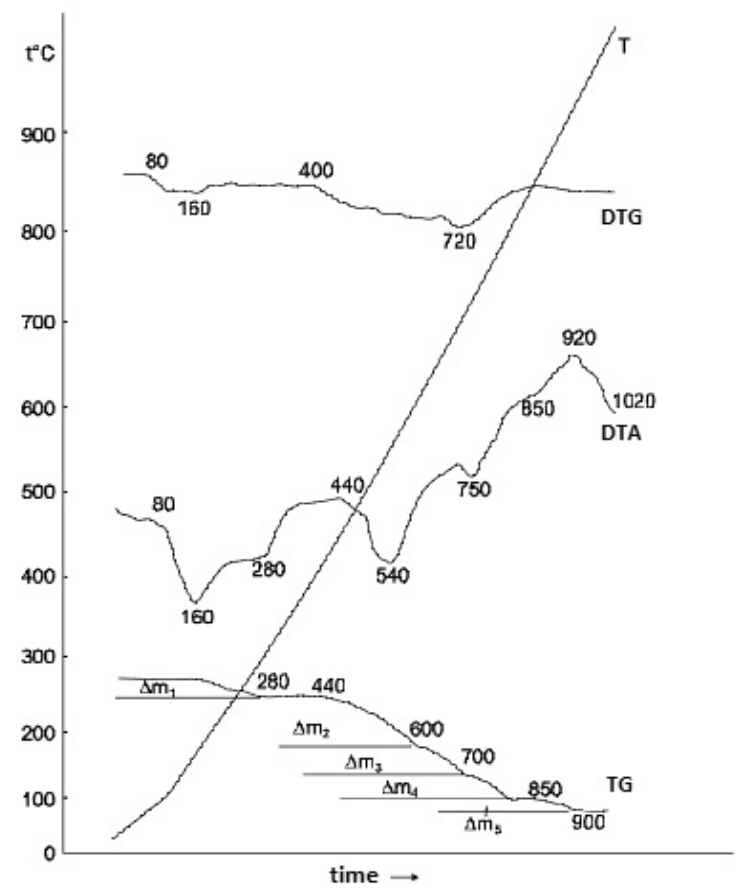

Figure 3. Thermocouple sample of the Krasnoyarsk clay subjected to additional abrasion

After the thermal analysis of the sample of the Krasnoyarsk clay, carried out in the temperature range up to $900{ }^{\circ} \mathrm{C}$, the phases of quartz, plagioclase dominate in the cinder material, the content of potassium feldspar is somewhat lowered, calcite, kaolinite, siderite, hematite, goethite, illite-smectiteare completely absent. The material retains traces of mica and a magnetite phase appears.

Based on the data obtained from the thermal analysis of the samples of the Krasnoyarsk clay (Fig. 3) and X-ray phase analysis data, the following sequence of thermal transformations occurring when the material of the Krasnoyarsk clay is heated can be represented.

Adsorbed water is removed in the temperature range of $\sim 80-160{ }^{\circ} \mathrm{C}$. Subsequently, within a range of up to $300{ }^{\circ} \mathrm{C}$, a partial removal of the crystallization water takes place. In the temperature range of $\sim 400$ $600{ }^{\circ} \mathrm{C}$, the destruction of mineral phases such as kaolinite occurs with the removal of structural (molecular) water and the formation of amorphous $\mathrm{Al}_{2} \mathrm{O}_{3}$ and $\mathrm{SiO}_{2}$. The decomposition of chlorite and magnesian calcite takes place with a further rise in temperature within $600-850^{\circ} \mathrm{C}$. The degradation products $\left(\mathrm{Al}_{2} \mathrm{O}_{3}, \mathrm{SiO}_{2}\right.$, $\mathrm{MgO}, \mathrm{CaO})$ formed in these temperature ranges are likely to acquire a plagioclase structure after subsequent heating $\left(>900^{\circ} \mathrm{C}\right)$, which explains the increase in its content in the material as a result of thermal exposure to the product under study.

The weight loss of the material occurs in the following sequence: within the limits of temperatures up to $280{ }^{\circ} \mathrm{C}-3,3 \%$, to $600{ }^{\circ} \mathrm{C}-6,7 \%$, to $700{ }^{\circ} \mathrm{C}-4,4 \%$, to $850{ }^{\circ} \mathrm{C}-3,3 \%$ and to $\sim 920{ }^{\circ} \mathrm{C}-2,2 \%$. The total mass loss is $19.9 \%$, which significantly exceeds (within 5-6\%) the decrease in the mass of the Sukpak clay.

Subsequent heating, exceeding $900{ }^{\circ} \mathrm{C}$, leads to complete decomposition of carbonate and hydrosilicate phases and promotes the process of transformation of amorphous phases formed as a result of the destruction of a wide range of aluminosilicates into plagioclase, spinel or mullite structures.

The stage-by-stage loss of mass that occurs during heating is due to the following factors, namely, removal of adsorption and crystallization water (endoeffects at $\sim 80-400{ }^{\circ} \mathrm{C}$ ) and decomposition of structures of aluminosilicates with removal of structural (molecular) moisture (endoeffects at $\sim 440-600{ }^{\circ} \mathrm{C}$ ); decomposition of magnesium calcite and siderite with the removal of $\mathrm{CO}_{2}$ (endoeffects at $\sim 600-850{ }^{\circ} \mathrm{C}$ ). 


\section{Conclusion}

The dynamics of the phase transformations in the clay samples of the clays of the Sukpak and Krasnoyarsk deposits that occur when they are heated in the temperature range up to $\sim 1020-1025^{\circ} \mathrm{C}$ is generally carried out according to the general scheme. Sorption and crystalline hydrate moisture is mainly removed in the region of low temperatures up to $\sim 400-450^{\circ} \mathrm{C}$. At temperatures in the region of $\sim 500-600{ }^{\circ} \mathrm{C}$ and with subsequent heating, the destruction of hydroaluminosilicate structures with the removal of crystallization (molecular) water, the release of amorphous oxide phases of silicon, aluminum and other metals included in these aluminosilicates occur. At subsequent heating in the temperature range of $\sim 600^{\circ} \mathrm{C}$ and higher, the decomposition of magnesian calcite with the removal of $\mathrm{CO}_{2}$ into the gas phase and the formation of successively amorphous magnesium oxide structures (up to $\sim 700-800^{\circ} \mathrm{C}$ ) and, further, calcium oxide (in the range above $800-850^{\circ} \mathrm{C}$ ) take place. At temperatures above $900^{\circ} \mathrm{C}$ in the material of the samples, new hightemperature aluminosilicate structures such as spinel, mullite, and plagioclase begin to form amorphous oxides. However, this does not lead to a volumetric and aggregate change. The material, as a rule, slightly hardened, but there was no appearance of liquid phases and even minimal sintering («grasping»). The products formed after the experiment with a little effort are scattered.

Some differences in the dynamics of phase transformations and in the composition of firing products of the Sukpak and Krasnoyarsk clays are determined by the difference in the phase composition of these clays.

\section{References}

1 Кара-сал Б.К. Химико-минералогические особенности месторождения глин и суглинков Тувы / Б.К. Кара-сал, В.И. Кудрявцев // Состояние и перспективы освоения природных ресурсов Тувы: сб. науч. тр. — Кызыл: ТувИКОПР СО PAH, 2002. - C. 100-105.

2 Кара-сал Б.К. Керамические строительные материалы, получаемые обжигом при пониженном давлении: автореф. дис. ... д-ра техн. наук: 05.23.05 - «Строительные материалы и изделия (технология, структура и изделия)» / Б.К. Кара-сал. - Новосибирск: СибСТРИН, 2007. - 36 с.

3 Кара-сал Б.К. Влияние пониженного давления на процессы газовыделения при обжиге глин / Б.К. Кара-сал // Стекло и керамика. - 2004. - № 9. - С. 18-20.

4 Лебедев В.И. Природные ресурсы Республики Тува: проблемы и перспективы их освоения: монография / В.И. Лебедев. - Кызыл: ТувИКОПР СО РАН, 2007. — 77 с.

5 Кара-сал Б.К. Прогнозирование технологических свойств керамических масс на основе химико-минералогических особенностей глинистых пород / Б.К. Кара-сал, Д.Х. Сат, У.Д. Чульдум // Естественные и технические науки. — 2009. № 1. - C. 371-375.

6 Кара-сал Б.К. Керамический материал на основе отходов извлечения кобальтового концентрата / Б.К. Кара-сал, Э.Э. Ондар, К.Л. Сат // Известия вузов. Строительство. — 2009. - № 8. - С. 32-36.

7 Кара-сал Б.К. Керамический материал на основе отходов кобальтового концентрата / Б.К. Кара-сал, М.С. Иргит, Ю.Д. Каминский // Техника и технология. - 2005. — № 5. - С. 63-66.

8 Копылов Н.И. Проблемы мышьяк-содержащих отвалов: монография / Н.И. Копылов. - Новосибирск: Академ. издво «ГЕО», 2012. - $182 \mathrm{c}$.

9 Atlas of thermoanalytical curves. — London; New York; Budapest: Akademiai Kiado, 1974. — Vol. 1-5.

10 Куликов Б.Ф. Минералогический справочник технолога-обогатителя: справ. изд. / Б.Ф. Куликов, В.В. Зуев, И.А. Вайншенкер, Г.А. Митенков. — Л.: Недра, 1985. — 264 с.

11 Бетехтин А.Г. Минералогия: монография / А.Г. Бетехтин. — М.: Гос. изд-во геолог. лит., 1950. — 956 с.

12 Горшков В.С. Термография строительных материалов: монография / В.С. Горшков. - М.: Изд-во лит. по строительству, 1968. - $237 \mathrm{c}$.

13 Пашкевич Л.А. Термография продуктов глинозёмного производства: справ. / Л.А. Пашкевич, В.А. Броневой, И.П. Краус. - М.: Металлургия, 1983. — 129 с.

14 Годовиков А.А. Минералогия: учебник / А.А. Годовиков. - М.: Недра, 1983. - 647 с.

15 Иванова В.П. Термический анализ минералов и горных пород: монография / В.П. Иванова, Б.К. Касатов, Т.Н. Красавина, Е.Л. Розинова. - Л.: Недра, 1974. - 399 с. 


\title{
Н.И. Копылов, Э.П. Солотчина
}

\section{Туваның Сукпак және Красноярск кен орындары топырақтарының термиялық қасиеттерін зерттеу}

\begin{abstract}
Жеке және алыс аймақтардың өнеркәсібі мен құрылыс индустриясы дамуы үшін маңызды факторлары болып шикізаттық және энергиялық базаларының болуы табылады. Әдетте, оларды тиімді пайдалану мүмкіндігі күрделі геологиялық жағдайлармен, қажетті транспорттық қатынасудың және өнеркәсіптік орталықтардан алыс орналасуымен қиындатылады. Мысалы, нақтылап айтқанда, Тува Республикасы өңірінде, алыс өңірлерде орналасқан және сондықтан олардың өңделуі қазіргі кезде тиімді болмайтын, шикізат кендерінің және топырақ шығарындаларын ондаған өнеркәсіптік қазбалар кені бар. Сондықтан негізгі шикізат көзі ретінде қолжетімді төмен сұрыптағы шикізатын әртүрлі қосымша компоненттер енгізу ақылы қолданылуы мүмкін. Осыған байланысты кешенді зерттеулердің белгілі көлемі қажет: бастапқы компоненттердің сипатталу динамикасын, олардың қоспаларын, қыздырғандағы шихталайтын құрамдарын зерттеу, жаңа шикізаттың қолдануымен технологиялар параметрлерін өңдеу т.б. Осыған байланысты осы жұмыстың бастапқы сатыларында физикахимиялық талдаулардың бірқатар әдістерін қолданып, Тувадағы Сукпак және Красноярск кен орындары топырақтарының төмен сұрыпты материалдарында, оларды $\sim 1020-1025^{\circ} \mathrm{C}$ дейін қыздырғандағы фазалық өзгерістердің динамикасы зерттелген. Нәтижесінде материалдың біртіндеп термиялық ыдырауындағы сатылары анықталды: сорбциялық және гидратты ылғалды жою, гидроалюмосиликаттарды деқұрылымдау, магнезиалды кальцитті ыдырату және жоғары температуралық алюмосиликатты құрылымдарды жаңадан қалыптастыру.
\end{abstract}

Кілm сөздер: рентгенфлуоресцентті, рентгенфазалық және термиялық талдаулар, топырақтар, оксидтер, силикаттар, алюмосиликаттар.

\section{Н.И. Копылов, Э.П. Солотчина}

\section{Изучение термических свойств глин Сукпакского и Красноярского месторождений Тувы}

\begin{abstract}
Важнейшим фактором развития промышленности и стройиндустрии отдельных и труднодоступных регионов является наличие у них соответствующей сырьевой и энергетической базы. Их возможное эффективное использование зачастую может быть затруднено вследствие сложных геологических условий, отсутствия требуемого транспортного сообщения и удаления от промышленных центров. Так, в частности, на территории Республики Тува известно более десятка промышленных залежей ископаемого сырья и пород глин, находящихся в труднодоступных районах, и их добыча в настоящее время нерентабельна. Поэтому в качестве основного сырья может быть использовано доступное низкосортное сырьё с введением различных дополнительных компонентов. Последнее требует определённого объёма комплексных исследований, таких как изучение динамики поведения исходных компонентов, их смесей, шихтующих составов при обжиге, отработка параметров технологии с использованием нового сырья и т.д. В связи с этим на первом этапе исследований в данной работе с использованием ряда методов физико-химического анализа изучена динамика фазовых преобразований, происходящих в материале низкосортных глин Сукпакского и Красноярского месторождений Тувы, при их нагреве в области температур до 1020-1025 ${ }^{\circ} \mathrm{C}$. В результате были определены этапы последовательного термического разложения материала: удаление сорбционной и гидратной влаги, деструктуризация гидроалюмосиликатов, разложение магнезиального кальцита и начальное формирование высокотемпературных алюмосиликатных структур.
\end{abstract}

Ключевые слова: термический, рентгенофазовый, рентгенофлуоресцентный анализы, глины, оксиды, карбонаты, силикаты, алюмосиликаты.

\section{References}

1 Kara-sal, B.K., \& Kudriavtsev, V.I. (2002). Khimiko-mineralohicheskie osobennosti mestorozhdeniia hlin i suhlinkov Tuvy [Chemical and mineralogical features of the clay and loam deposits of Tuva]. Sostoianie i perspektivy osvoeniia prirodnykh resursov Tuvy - State and prospects of natural resources development in Tuva. Kyzyl: TIKOPR SB RAS [in Russian].

2 Kara-sal, B.K. (2007). Keramicheskie stroitelnye materialy, poluchaemye obzhihom pri ponizhennom davlenii [Ceramic building materials obtained by firing under reduced pressure]. Extended abstract of Doctor's thesis. Novosibirsk [in Russian].

3 Kara-sal, B.K. (2004). Vliianie ponizhennoho davleniia na protsessy hazovydeleniia pri obzhihe hlin 「Influence of a reduced pressure on the processes of gas evolution during clays firing]. Steklo i keramika - Glass and ceramics, 9, 18-20 [in Russian]. 
4 Lebedev, V.I. (2007). Prirodnye resursy Respubliki Tyva: problemy i perspektivy ikh osvoeniia [Natural resources of the Republic of Tuva: problems and prospects for their development]. Kyzyl: TIKOPR SB RAS [in Russian].

5 Kara-sal, B.K., Sat, D.Kh., \& Chuldum, U.D. (2009). Prohnozirovanie tekhnolohicheskikh svoistv keramicheskikh mass na osnove khimiko-mineralohicheskikh osobennostei hlinistykh porod [Prediction of technological properties of ceramic masses on the basis of chemical-mineralogical features of clay rocks]. Yestestvennye $i$ tekhnicheskie nauki - Natural and technical sciences, 1 , 371-375 [in Russian].

6 Kara-sal, B.K., Ondar, E.E., \& Sat, K.L. (2009). Keramicheskii material na osnove otkhodov izvlecheniia kobaltovoho kontsentrata [Ceramic material based on cobalt concentrate waste]. Izvestiia vuzov. Stroitelstvo - Proceedings of universities. Building, 8, 32-36 [in Russian].

7 Kara-sal, B.K., Irgit, M.S., \& Kaminskii, Yu.D. (2005). Keramicheskii material na osnove otkhodov kobaltovoho kontsentrata [Ceramic material based on the waste of cobalt concentrate]. Tekhnika i tekhnolohiia - Engineering and technology, 5, 63-66 [in Russian].

8 Kopylov, N.I. (2012). Problemy myshiak-soderzhashchikh otvalov [Problems of arsenic-containing dumps]. Novosibirsk: Akadem. izdatelstvo «GEO» [in Russian].

9 Atlas of thermoanalytical curves (1974). (Vols. 1-5). London; New York; Budapest: Akademiai Kiado.

10 Kulikov, B.F., Zuyev, V.V., Vainshenker, I.A., \& Mitenkov, G.A. (1985). Mineralohicheskii spravochnik tekhnolohaobohatitelia [Mineralogical handbook of the enriching technologist]. Leningrad: Nedra [in Russian].

11 Betekhtin, A.G. (1950). Mineralohiia [Mineralogy]. Moscow: Hos. izdatelstvo heolohicheskoi literatury [in Russian].

12 Gorshkov, V.S. (1968). Termohrafiia stroitelnykh materialov [Thermography of building materials]. Moscow: Izdatelstvo literatury po stroitelstvu [in Russian].

13 Pashkevich, L.A., Bronevoi, V.A., \& Kraus, I.P. (1983). Termohrafiia produktov hlinoziomnoho proizvodstva [Thermography of products of alumina production]. Moscow: Metallurhiia [in Russian].

14 Godovikov, A.A. (1983). Mineralohiia [Mineralogy]. Moscow: Nedra [in Russian].

15 Ivanova, V.P., Kasatov, B.K., Krasavina, T.N., \& Rozinova, Ye.L. (1974). Termicheskii analiz mineralov $i$ hornykh porod [Thermal analysis of minerals and rocks]. Leningrad: Nedra [in Russian]. 